\section{BIOSYNTHESIS OF LEUPEPTIN}

\author{
Makoto Hori*, Hiromichi Hemmi, \\ Kayoko Suzukake and Hidemi Hayashi \\ Showa College of Pharmaceutical Sciences, \\ Tsurumaki 5-1-8, Setagaya-ku, Tokyo, \\ 154, Japan \\ Yoshimasa Uehara, Tomio Takeuchi \\ and Hamao Umezawa \\ Institute of Microbial Chemistry \\ Kamiosaki 3-14-23, Shinagawa-ku, Tokyo, \\ 141, Japan
}

(Received for publication August 30, 1977)

Leupeptins were isolated from culture filtrates of several strains of streptomyces on the basis of their antiplasmin activity. Their structures were determined to be propionyl- and acetylL-leucyl-L-leucyl-L-argininal and the analogs in which one or both leucine residues are replaced by isoleucine or valine residues ${ }^{1}$. Biosynthesis of leupeptins, primarily of acetyl-leucyl-leucylargininal, has recently been studied with Streptomyces roseus MA839-A1 in the following manner: (1) The efficiency of incorporation of various radioactive precursors into leupeptin under fermentation conditions was determined. (2) Some labeled leupeptins obtained in this manner were degraded and the location of the radioactivity in the products determined. (3) An attempt was made to obtain a cell-free system synthesizing leupeptin. We report here on recent progress in these efforts.

Mycelium of the leupeptin-producing strain was shaken-cultured at $27^{\circ} \mathrm{C}$ in a synthetic medium containing leucine, arginine and glucose (LAG medium), as reported ${ }^{2)}$. A preliminary experiment indicated that, under these conditions, leucine and arginine were essential for maximum production of leupeptin and were utilized in its production (data not shown). The incorporation of various radioactive precursors into leupeptin was determined (Table 1). The following points are evident: (1) As the preliminary experiment suggested, leucine and arginine were good precursors, followed by isoleucine, sodium acetate and so on in decreasing order. (2) Both [U- $\left.{ }^{14} \mathrm{C}\right]-\mathrm{Arg}$ and [guanido- ${ }^{14} \mathrm{C}$ Arg were incorporated equally well, while $\left[\mathrm{G}-{ }^{3} \mathrm{H}\right]-$ ornithine was only slightly incorporated. This

* To whom requests for reprints should be directed.
Table 1. Incorporation efficiency of various radioactive precursors into leupeptin under fermentation conditions

\begin{tabular}{|c|c|}
\hline Precursors & $\begin{array}{c}\text { Incorporation } \\
\text { efficiencies }\end{array}$ \\
\hline $\mathrm{L}-\left[\mathrm{U}-{ }^{14} \mathrm{C}\right]$-Leucine & $29.6(\%)$ \\
\hline L-[U- $\left.{ }^{14} \mathrm{C}\right]$-Isoleucine & 3.74 \\
\hline $\mathrm{L}-\left[\mathrm{U}-{ }^{14} \mathrm{C}\right]-$ Valine & 0.33 \\
\hline $\mathrm{L}-\left[\mathrm{U}-{ }^{14} \mathrm{C}\right]$-Arginine & 17.4 \\
\hline L-[Guanido- $\left.{ }^{14} \mathrm{C}\right]$-Arginine & 22.4 \\
\hline$\left[\mathrm{U}-{ }^{14} \mathrm{C}\right]$-Glycine & 2.05 \\
\hline $\mathrm{D}-\left[\mathrm{U}-{ }^{14} \mathrm{C}\right]-$ Glucose & 0.95 \\
\hline $\mathrm{D}-\left[1-{ }^{14} \mathrm{C}\right]-$ Glucosamine & 1.89 \\
\hline $\mathrm{D}-\left[\mathrm{U}-{ }^{14} \mathrm{C}\right]-\mathrm{Ribose}$ & 0.52 \\
\hline$\left[1-{ }^{14} \mathrm{C}\right]-$ Glycerol & 0.74 \\
\hline$\left[1-{ }^{14} \mathrm{C}\right]$-Sodium acetate & 3.51 \\
\hline $\mathrm{L}-\left[\mathrm{U}-{ }^{14} \mathrm{C}\right]$-Glutamine & 0.42 \\
\hline L-[U- $\left.{ }^{14} \mathrm{C}\right]-$ Glutamic acid & 0.43 \\
\hline DL-[G- $\left.{ }^{3} \mathrm{H}\right]-$ Ornithine & 0.04 \\
\hline$\left[1-{ }^{14} \mathrm{C}\right]-$ Acetyl-L-[G- $\left.{ }^{3} \mathrm{H}\right]$-leucine & $\begin{array}{l}0.94\left({ }^{14} \mathrm{C}\right) \\
0.64\left({ }^{3} \mathrm{H}\right)\end{array}$ \\
\hline $\begin{array}{l}{\left[1-{ }^{-14} \mathrm{C}\right]-\text { Acetyl-L-leucyl- }} \\
\left.\text { L-[G- }{ }^{3} \mathrm{H}\right] \text {-leucine }\end{array}$ & $\begin{array}{l}0.19\left({ }^{14} \mathrm{C}\right) \\
0.23\left({ }^{3} \mathrm{H}\right)\end{array}$ \\
\hline
\end{tabular}

Radioactive precursors, each added to a set of four $125 \mathrm{ml}$ cultures, were $\left[\mathrm{U}-{ }^{14} \mathrm{C}\right]$-L-leucine $(7.9$ $\mathrm{mCi} / \mathrm{mmole} ; 10 \mu \mathrm{Ci}), \mathrm{L}-\left[\mathrm{U}-{ }^{14} \mathrm{C}\right.$-isoleucine $(10 \mathrm{mCi} /$ mmole; $10 \mu \mathrm{Ci}), \mathrm{L}-\left[\mathrm{U}-{ }^{14} \mathrm{C}\right]$-valine $(10 \mathrm{mCi} / \mathrm{mmole}$; $10 \mu \mathrm{Ci}), \mathrm{L}-\left[\mathrm{U}-{ }^{14} \mathrm{C}\right]$-arginine $(240 \mathrm{mCi} / \mathrm{mmole} ; 26.8$ $\mu \mathrm{Ci}), \quad$ L-[guanido- ${ }^{14} \mathrm{C}$-arginine $(25.9 \mathrm{mCi} / \mathrm{mmole}$; $13.2 \mu \mathrm{Ci}), \quad\left[\mathrm{U}_{-}{ }^{14} \mathrm{C}\right]$-glycine $(10.2 \mathrm{mCi} / \mathrm{mmole} ; 10$ $\mu \mathrm{Ci}), \mathrm{D}-\left[\mathrm{U}-{ }^{14} \mathrm{C}\right]$-glucose $(5.0 \mathrm{mCi} / \mathrm{mmole} ; 5 \mu \mathrm{Ci})$, D-[1-14 C]-glucosamine $(3.1 \mathrm{mCi} / \mathrm{mmole} ; 5 \mu \mathrm{Ci})$, D[U- $\left.{ }^{14} \mathrm{C}\right]$-ribose $(18.1 \mathrm{mCi} / \mathrm{mmole} ; 10 \mu \mathrm{Ci}),\left[1{ }^{14} \mathrm{C}\right]-$ glycerol $(4.7 \mathrm{mCi} / \mathrm{mmole} ; 10 \mu \mathrm{Ci}),\left[1-{ }^{14} \mathrm{C}\right]$-sodium acetate $(10.0 \mathrm{mCi} / \mathrm{mmole} ; 10 \mu \mathrm{Ci}), \mathrm{L}-\left[\mathrm{U}_{-}{ }^{14} \mathrm{C}\right]$-glutamine $(36.4 \mathrm{mCi} / \mathrm{mmole} ; 10 \mu \mathrm{Ci}), \mathrm{L}-\left[\mathrm{U}-{ }^{14} \mathrm{C}\right.$-glutamic acid $(66.0 \mathrm{mCi} / \mathrm{mmole} ; 10 \mu \mathrm{Ci}), \quad$ DL-[G- $\left.{ }^{3} \mathrm{H}\right]$-ornithine $(100 \mathrm{mCi} / \mathrm{mmole} ; 20 \mu \mathrm{Ci}),\left[1{ }^{14} \mathrm{C}\right]$-acetyl-L[4.5- $\left.{ }^{3} \mathrm{H}\right]$-leucine $\left(3.61 \mu \mathrm{Ci}^{14} \mathrm{C} /\right.$ mmole and $21.0 \mu \mathrm{Ci}^{3} \mathrm{H} /$ mmole; $11 \mu \mathrm{Ci}^{14} \mathrm{C}$ and $\left.64 \mu \mathrm{Ci}^{3} \mathrm{H}\right)$, and [1${ }^{14} \mathrm{C}$-acetyl-L-leucyl-L-[4.5- $\left.{ }^{8} \mathrm{H}\right]$-leucine $\left(6.02 \mu \mathrm{Ci}^{14} \mathrm{C} /\right.$ mmole and $13.4 \mu \mathrm{Ci}{ }^{3} \mathrm{H} /$ mmole; $11 \mu \mathrm{Ci}^{14} \mathrm{C}$ and 24 $\mu \mathrm{Ci}^{3} \mathrm{H}$ ). The last 2 precursors were synthesized in the author's laboratory ${ }^{3,4)}$. The culture conditions were as reported ${ }^{2}$ except that the concentration of arginine in LAG-medium was reduced to $1.7 \mathrm{mg} / \mathrm{ml}$. The radioactive precursors were added to the cultures at 24 hours of incubation and the fermentation was continued for another 24 hours. After termination of incubation, the culture broths of four bottles (one set) were combined and centrifuged. From the supernatant, a 1-ml sample was taken for assay for the leupeptin 
concentration based on antitryptic activity ${ }^{5)}$, while the remainder was used for isolation of leupeptin by procedures consisting of ion-exchange resin column chromatography, extraction with butanol, and paper electrophoresis ${ }^{1}$ (see also Legend to Table 3). Radioactivity localized in purified leupeptin was corrected for the recovery of leupeptin throughout these isolation procedures. Radioactivity measurements were made in a liquid scintillation counter.

Table 2. Distribution ( $\%$ ) of radioactivity among the leupeptin moieties

\begin{tabular}{|c|c|c|c|}
\hline $\begin{array}{l}\text { Radioactive } \\
\text { precursors }\end{array}$ & $\mathrm{CH}_{3} \mathrm{CO}$ & Leu & $\overbrace{\text { Guanido Ornithina }}^{\text {Argininal }}$ \\
\hline $\mathrm{CH}_{3}{ }^{14} \mathrm{COONa}$ & 93.6 & 6.4 & 0 \\
\hline $\mathrm{L}-\left[\mathrm{U}-{ }^{14} \mathrm{C}\right]-\mathrm{Leu}$ & 3.2 & 87.9 & $\begin{array}{r}1.9 \\
68.0\end{array}$ \\
\hline $\begin{array}{l}\left.\text { L-[Guanido- }{ }^{14} \mathrm{C}\right]- \\
\quad \text { Arg }\end{array}$ & 26.8 & 5.2 & $\overbrace{66.4} 1.6$ \\
\hline $\mathrm{L}-\left[\mathrm{U}-{ }^{14} \mathrm{C}\right]-\mathrm{Arg}$ & 34.6 & 6.9 & $\overbrace{7.0} \underbrace{}_{51.5}$ \\
\hline
\end{tabular}

Each labeled leupeptin was oxidized with potassium permanganate to leupeptin acid, from which L-leucine and D,L-arginine were derived by acid hydrolysis ${ }^{2,3)}$. In the case of arginine-labeled leupeptin, the $\mathrm{D}, \mathrm{L}$-arginine was further hydrolyzed with $\mathrm{Ba}(\mathrm{OH})_{2}$ to give D,L-ornithin, $\mathrm{NH}_{3}$ and $\mathrm{CO}_{2}$ (as $\left.\mathrm{BaCO}_{3}\right)^{6)}$; e.g., $10 \mathrm{mg}$ of the $\mathrm{D}$, L-arginine was dissolved in $2 \mathrm{ml}$ of water, mixed with $3 \mathrm{ml}$ of saturated $\mathrm{Ba}(\mathrm{OH})_{2}$ solution, heated at $95^{\circ} \mathrm{C}$ for 2 hours, chilled and filtered. The precipitate of $\mathrm{BaCO}_{3}$, collected on a filter, was washed with water and methanol, dried and submitted to radioactivity measurement. The filtrate received a small piece of dry ice and was filtered (excess $\mathrm{Ba}(\mathrm{OH})_{2}$ was removed as $\left.\mathrm{BaCO}_{3}\right)$. The precipitate collected on a filter was washed twice with $2 \mathrm{ml}$ of water. The washes and the filtrate were combined and concentrated in vacuo yielding $28.8 \mathrm{mg}$ of residue, from which $\mathrm{D}$, L-ornithine was isolated by thin-layer chromatography ( 5 plates of Avicel S7, $20 \times 20 \mathrm{~cm}$, developed with $\mathrm{BuOH}$ $\mathrm{AcOH}$ - water; 4:1:1, $\mathrm{Rf}=0.1$ ). Quantitative determination of amino acids was performed by a color reaction with trinitrobenzenesulfonate. Radioactivities of degradation products were corrected for their recoveries during the chemical procedures. Distribution of radioactivity in $\mathrm{CH}_{3} \mathrm{CO}$ was obtained by subtracting Leu $(\%)$ and Arg $(\%)$ from $100(\%)$.

suggested that both the guanido and ornithine moieties of arginine were incorporated together. (3) The incorporation of isoleucine possibly reflects the biosynthesis of analogs in which one or both leucine residues were replaced by isoleucine. (4) The incorporation efficiency of sodium acetate was obviously higher than that of nonprecursors, although the efficiency was somewhat lower than with leucine and arginine. (5) Acetylleucine and acetyl-leucyl-leucine were only slightly incorporated into leupeptin of intact cells. This is in contrast to the result of cell-free synthesis (see below; Table 3) where these peptides were good precursors. The cells may be impermeable to these intermediate peptides or the peptides may be hydrolyzed by the cell membrane. However, the latter possibility could be ruled out because these intermediate peptides did not stimulate but rather inhibited the production of leupeptin (data not shown).

We wished to determine if radioactive acetate, leucine and arginine were directy incorporated into the corresponding moieties of leupeptin. The leupeptins labeled with each of these precursors were degraded and the distribution of radioactivity among the products was determined. As Table 2 shows, there was a good correlation between the precursors and the Jabeled moieties. Some arginine-derived radioact vity was found in the acetyl moiety, however.

Nonribosomal synthesis of peptides, catalyzed by multienzyme systems, is established for gramicidin, tyrocidin, et cetera ${ }^{7)}$. This mechanism, as opposed to ribosomal synthesis, allows some substitution of component amino acids by structurally related ones. Production of various leupeptin analogs under fermentation conditions suggested nonribosomal synthesis. We initiated a study to confirnı this possibility and also to answer questions such as when and how the N-terminal is acylatec and when and how the C-terminal carboxyl is reduced to aldehyde. As a first step toward these objectives, an attempt was made to find enzymatic activity synthesizing leupeptin, and/or its intermediates, in a cell-free extract of this striin. As Table 3 shows, the cell-free extract, when supplemented with ATP and the other components, was capable of synthesizing leupeptin acid (acetylleucyl-leucyl-arginine) from any of the following combinations of the substrates; $(\pi)$ sodium acetate, leucine and $\left[{ }^{14} \mathrm{C}\right]$-arginine, (I]) acetyl-leucine, leucine and $\left[{ }^{14} \mathrm{C}\right]$-arginine, and (III) acetylleucyl-leucine and $\left[{ }^{14} \mathrm{C}\right]$-arginirie. The rate of conversion of a given amount of $\left[{ }^{14} \mathrm{C}\right]$-arginine 
Table 3. Cell-free synthesis of leupeptin acid

\begin{tabular}{|c|c|}
\hline Substrates & $\begin{array}{c}{\left[{ }^{14} \mathrm{C}\right]-} \\
\text { Leupeptin } \\
\text { acid formed } \\
(\mathrm{dpm})\end{array}$ \\
\hline $3 \mathrm{~mm} \mathrm{AcONa}+6 \mathrm{~mm} \mathrm{Leu}+\left[{ }^{14} \mathrm{C}\right]-\mathrm{Arg}$ & 1,258 \\
\hline $3 \mathrm{~mm}$ AcLeu $+3 \mathrm{~mm} \mathrm{Leu}+\left[{ }^{14} \mathrm{C}\right]$-Arg & 15,812 \\
\hline $3 \mathrm{~mm}$ AcLeuLeu $\quad+\left[{ }^{14} \mathrm{C}\right]$-Arg & 94,226 \\
\hline
\end{tabular}

Fermentation was performed in an enriched medium as reported. ${ }^{1)}$ The mycelia, harvested from 4 culture flasks at 24 hours of cultivation, were washed twice with cold $20 \mathrm{~mm}$ Tris $\cdot \mathrm{HCl}$ buffer, $\mathrm{pH} 8$, giving $6 \mathrm{~g}$ of mycelial paste. The paste was suspended in $30 \mathrm{ml}$ of $20 \mathrm{~mm}$ Tris. $\mathrm{HCl}$, $\mathrm{pH} 8$, treated with DNase at $5 \mu \mathrm{g} / \mathrm{ml}$, and submitted to cell-desruption by twice-repeated passages through a French pressure cell $(17,000$ psi). The homogenate was centrifuged at $10,000 \mathrm{~g}$ for 20 minutes and the supernatant was dialyzed against $20 \mathrm{~mm}$ Tris $\cdot \mathrm{HCl}$ ( $\mathrm{pH}$ 8)-2 mм $\mathrm{MgCl}_{2}-5 \mathrm{~mm}$ mercaptoethanol. All procedures were performed below $10^{\circ} \mathrm{C}$. The dialyzed solution $(7.5 \mathrm{mg}$ protein $/ \mathrm{ml}$ ) was used as crude enzyme. A reaction mixture for the cell-free synthesis of leupeptin acid contained in $250 \mu \mathrm{l}, 0.1 \mathrm{M}$ Tris $\cdot \mathrm{HCl}, \mathrm{pH} 9.0$, $2 \mathrm{~mm}$ ATP, $50 \mathrm{~m} \mu \mathrm{Ci}$ of $\left[{ }^{14} \mathrm{C}\right]$-arginine $(30 \mathrm{mCi} /$ mmole), N-terminal component(s) (see below*), $2 \mathrm{mM} \mathrm{MgCl}_{2}, 2 \mathrm{~mm}$ dithiothreitol, $10 \mu \mathrm{M}$ leupeptin (see below**), $150 \mu \mathrm{g}$ protein of the crude enzyme, and water to volume. The incubation was performed at $27^{\circ} \mathrm{C}$ for $15 \mathrm{~min}$ and the reaction was terminated by quick mixing with $1.5 \mathrm{ml}$ of butanolsaturated water and $1.75 \mathrm{ml}$ of water-saturated butanol. After centrifugation at $1,000 \mathrm{~g}$ for 10 minutes, an aliquot of the butanol layer, $1.2 \mathrm{ml}$, was washed with $0.5 \mathrm{ml}$ of butanol-saturated water by mixing and centrifugation and $0.2 \mathrm{ml}$ was taken for a radioactivity measurement (sum of leupeptin and leupeptin acid). From the remainder, $0.8 \mathrm{ml}$ was concentrated to dryness in vacuo below $50^{\circ} \mathrm{C}$. The residue, together with about $10 \mu \mathrm{g}$ of carrier leupeptin acid, was dissolved in a minimum volume of methanol, applied to paper (Toyo No. 514, $10 \times 40 \mathrm{~cm}$ ) and submitted to electrophores is at 1,200 volt for 1 hour with a solvent system of acetic acid-pyridine - water (10: 0.4:90, v/v), pH 6.0. Leupeptin and leupeptin acid were localized by the RYDON-SMITH color reaction.

The leupeptin area of the electrophoretogram carried less than $1.0 \%$ of the total radioactivity.

* Any of I, II and III; (I) 3 mm sodium acetate and $6 \mathrm{~mm}$ leucine, (II) $3 \mathrm{~mm}$ acetyl-leucine and 3 mM leucine and (III) 3 mm acetyl-leucyl-leucine.

** Leupeptin apparently stimulated the reaction catalyzed by a crude extract probably by inhibiting some contaminating peptidases.
Fig. 1. Proof of cell-free synthesis of leupeptin.

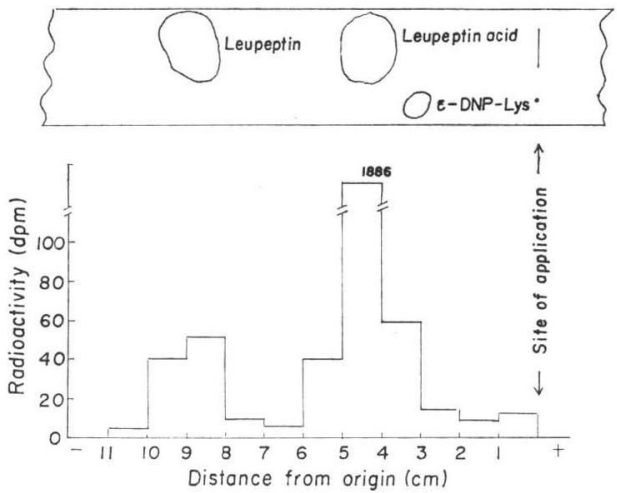

The experiment was conducted as described under the legend to Table 3 except the following modification: (1) Cell-extract was prepared from a mixture of the mycelium which was withdrawn from fermentation at day 1, 2 and 3 and the extract was examined for the enzyme activity soon after its preparation, without dialysis. (2) $3 \mathrm{~mm}$ acetyl-leucyl-leucine was the $\mathrm{N}$-terminal component. (3) Leupeptin was not included in the reaction mixture. (4) $10 \mathrm{~mm}$ NADPH was added to the reaction mixture. (5) About $10 \mu \mathrm{g}$ of leupeptin was co-electrophoresed as carrier.

into $\left[{ }^{14} \mathrm{C}\right]$-leupeptin acid was in the increasing order of (I), (II) and (III). None of these reactions were inhibited by chloramphenicol or the treatment with RNase (data not shown). With a fresh cell-extract, $\left[{ }^{14} \mathrm{C}\right]$-leupeptin was also synthesized in a detectable amount from acetyl-leucyl-leucine and $\left[{ }^{14} \mathrm{C}\right]$-arginine (Fig. 1). The same cell-extract, after storage for several days at $-80^{\circ} \mathrm{C}$, gave no $\left[{ }^{14} \mathrm{C}\right]$-leupeptin but an almost unchanged amount of $\left[{ }^{14} \mathrm{C}\right]$-leupeptin acid under similar reaction conditions (data not shown). To increase the synthesis of leupeptin, various attempts were made; (1) addition of NADPH or NADH into the reaction mixture, (2) choice of suitable age of mycelia for cellextract, that is, day 1,2 or 3 of fermentation, and (3) use of cell-homogenate (without centrifugation at $10,000 \times g$ ) instead of cell-extract (supernatant at $10,000 \times g$, dialyzed) to examine possible role of the membrane. None was effective, however (data not shown). Characterization of these enzymes is in progress.

\section{References}

1) Aoyagi, T.; T. Takeuchi, A. Matsuzaki, K. 
Kawamura, S. Kondo, M. Hamada, K. Maeda \& H. Umezawa: Leupeptins, new protease inhibitors from actinomycetes. J. Antibiotics 22: $283 \sim 286,1969$

2) Kondo, S.; K. Kawamura, J. Iwanaga, M. Hamada, T. Aoyagi, K. Maeda, T. Takeuchi \& H. UMEZAWA: Isolation and characterization of leupeptins produced by actinomycetes. Chem. Pharm. Bull. 17: 1896 1901, 1969

3) Kawamura, K.; S. Kondo, K. Maeda \& H. UMEZAWA: Structures and syntheses of leupeptins Pr-LL and Ac-LL. Chem. Pharm. Bull. 17: $1902 \sim 1909,1969$
4) Dewit, H. D. \& W. Iugersoll: The preparation of pure N-acetyl-L-leucire and L-leucine. J. Am. Chem. Soc. 73: 3359 3360, 1951

5) Aoyagi, T.; S. Miyata, M. Nanbo, F. Kojima, M. Matsuzaki, M. IshizuKa, T'. TAKeuchi \& H. UMEZAWA: Biological activities of leupeptins. J. Antibiotics 22: 558 568, 1969

6) Seto, H.; I. Yamaguchi, N. ŌTake \& H. YoneHARA: Studies on the biosynthesis of blasticidin S. I. Precursors of blasticidin S biosynthesis. Agr. Biol. Chem. 32: 1292 1298, 1968

7) Kurahashi, K.: Biosynthesis of small peptides. Ann. Rev. Biochem. 43: 445 459, 1974 